\title{
Urban Rivers as Dispersal Corridors: Which Factors Are Important for the Spread of Alien Woody Species along the Danube?
}

\author{
Sabrina Wagner, Dietmar Moser and Franz Essl * \\ Division of Conservation, Vegetation and Landscape Ecology, Department of Botany and Biodiversity Research, \\ University Vienna, 1030 Wien, Austria; wagnersabrina00@gmail.com (S.W.); dietmar.moser@univie.ac.at (D.M.) \\ * Correspondence: franz.essl@univie.ac.at; Tel.: +43-1-4277-54072
}

Received: 1 February 2020; Accepted: 2 March 2020; Published: 11 March 2020

check for updates

\begin{abstract}
Cities are hotspots of invasions, and this is particularly the case for urban rivers, which are known to serve as corridors for the spread of alien plant species to floodplain forests. Here, we present a case study on woody (shrubs, trees) species invasions across a gradient from a metropolis (Vienna) to rural regions along the Danube River in eastern Austria. In total, we identified 44 native and 25 alien woody species in 75 plots. Five alien woody species occur in at least 10 plots. The most wide-spread ones were species of floodplain forests (Acer negundo, Fraxinus pennsylvanica, and Populus $x$ canadensis), while Ailanthus altissima and Robinia pseudoacacia—which prefer dry sites-were recorded substantially less often. The average level of invasion-i.e., the relative proportion of alien to native woody species in plots-was high across all three study regions. Still, there was a moderate decline of alien woody species richness along the urban-peri-urban-rural gradient. Generalized Linear Mixed Models showed that population density and the proportion of urban habitats in the environs of the plots is significantly positively correlated with the presence of Acer negundo and Ailanthus altissima. Conversely, the occurrence of Robinia pseudoacacia is negatively correlated with surrounding population density and urban habitats. Occurrence of Acer negundo is positively correlated with urban habitats. For Fraxinus pennsylvanica, we found no significant relationships. Our results confirm that gallery forests at river banks are highly susceptible to invasions. We argue that managing alien woody species in urban and peri-urban sites is not appropriate and useful, given that re-invasion is likely in most cases (from adjacent urban green spaces). We acknowledge that this recommendation entails the implicit recognition that gallery forests along urban sections of the Danube will contain a substantial—and likely further increasing—proportion of alien woody species.
\end{abstract}

Keywords: alien species; biological invasions; distribution; management; rivers; urban ecology; woody plants

\section{Introduction}

Biological invasions have become a significant component of global environmental change [1]. While levels of invasions are highly uneven among habitats in Central Europe [2], they are particularly high in urban-industrial habitats, gardens, and public green spaces [3]. Accordingly, due to high levels of anthropogenic disturbance and propagule pressure, urban environments have become a hotspot of biological invasions $[4,5]$.

Humans are altering the biophysical world with unprecedented velocity, and one of the eminent drivers is increasing urbanization. Accordingly, cities have grown rapidly due to immigration from rural areas, and due to endogenous population growth. On average, $25 \%$ of the global population has moved from rural into urban settlements during the past six decades, and this trend is expected to continue [5]. Concomitantly, the number of alien plants and animals in urban regions has increased $[5,6]$. 
It has been shown that alien-but also native-plant species richness is significantly higher in cities than in surrounding agricultural landscapes $[4,7,8]$. The high urban plant diversity is caused by pronounced habitat heterogeneity linked to small-scale variations in land use, site conditions, and disturbance, including often remnants of extensively used habitats from cultural landscapes in peri-urban regions [4,7]. Further, ornamental horticulture in public spaces and private gardens is causing high levels of propagule pressure of alien plant species in urban settlements [9]. In addition, cities act as heat islands that facilitate the spread of thermophilic species. These effects combined increase in intensity from the periphery towards the centers of cities [10].

Dispersal corridors such as transport infrastructure (roads, railways) [11] and river networks play an important role for the spread of alien species [12,13]. Accordingly, running waters have been shown to be very effective conduits for the spread of some alien species [14,15]. The centers of large cities often encompass sections of rivers that serve as dispersal corridors for aquatic and riparian species [8] — particularly so for species that produce floating seeds or can be dispersed by floating rhizomes [14,15].

Woody species (trees, shrubs, lianas) contribute only a moderate proportion to the alien global flora [16]. Currently, $0.5 \%$ of the world's tree species and $0.7 \%$ of the world's shrub species are invasive outside their native range [17]. This represents 622 species, of which 357 are trees and 265 shrubs. However, in many parts of the world, alien woody species are among the most invasive species [18]. Once they are established, they are very difficult to eradicate. Thus, it is argued that urban centers-and rivers in cities-may serve as a hub for the further spread of alien species into surrounding environments [19]. A better understanding of the factors that determine woody plant species invasions along rivers along an urban-peri-urban-rural gradient is highly important to improve alien species management strategies.

Here, we present a case study of woody plant invasions along the Danube River in eastern Austria and along a gradient from urban to rural areas. We selected three different sections of the Danube River in and near Vienna and sampled native and alien woody species composition in plots in these study regions. Specifically, we addressed the following research questions: (1) What is the proportion of alien woody species in different sections of the Danube River in eastern Austria? (2) Which alien woody species are the most common ones? (3) How does alien woody species abundance change along the urban-rural gradient? (4) Which factors explain the distribution of alien woody species? We hypothesized that richness of alien woody species decreases from urban to rural rivers sections and that this decline in alien woody species richness is related to anthropogenic habitat modification (e.g., local population density, vicinity of major streets, and railways) that affect and propagule pressure and invasibility $[5,7]$.

\section{Materials and Methods}

\subsection{Study Region and Sites}

The study region is located in eastern Austria in and near Vienna (Figure 1). It consists of three sections located along the Danube River. With a total length of $2850 \mathrm{~km}$ and an average discharge of $7000 \mathrm{~m}^{3} / \mathrm{s}$ at the river mouth, the Danube is largest river of Central and Western Europe [20]. In eastern Austria, the Danube is characterized by spring and summer floods after snow melt and heavy precipitation events in the catchments of its alpine tributaries. The climate of Vienna is temperate Pannonian, with cool winters and warm summers, the average annual temperature is $10.4{ }^{\circ} \mathrm{C}$ and annual precipitation is 500-650 mm (1981-2010) [21]. In Austria, the Danube is characterized by substantial river slope of $40 \mathrm{~cm} / \mathrm{km}$, large amounts of gravel being transported, and thus it is classified as an alpine river. Until the 19th century, the Danube was characterized by a braided river system that was several kilometers wide in places [20]. The Danube was channelized in the late 19th and early 20th century, and protective dikes were established, while several hydroelectric power plants were built from the mid-20th century onward. As a result, rarely flooded hardwood floodplain forests increased 
at the expanse of pioneer gravel banks and softwood floodplain forests (dominated by Salix spp., Populus spp.) that are adapted to regular flooding [22].
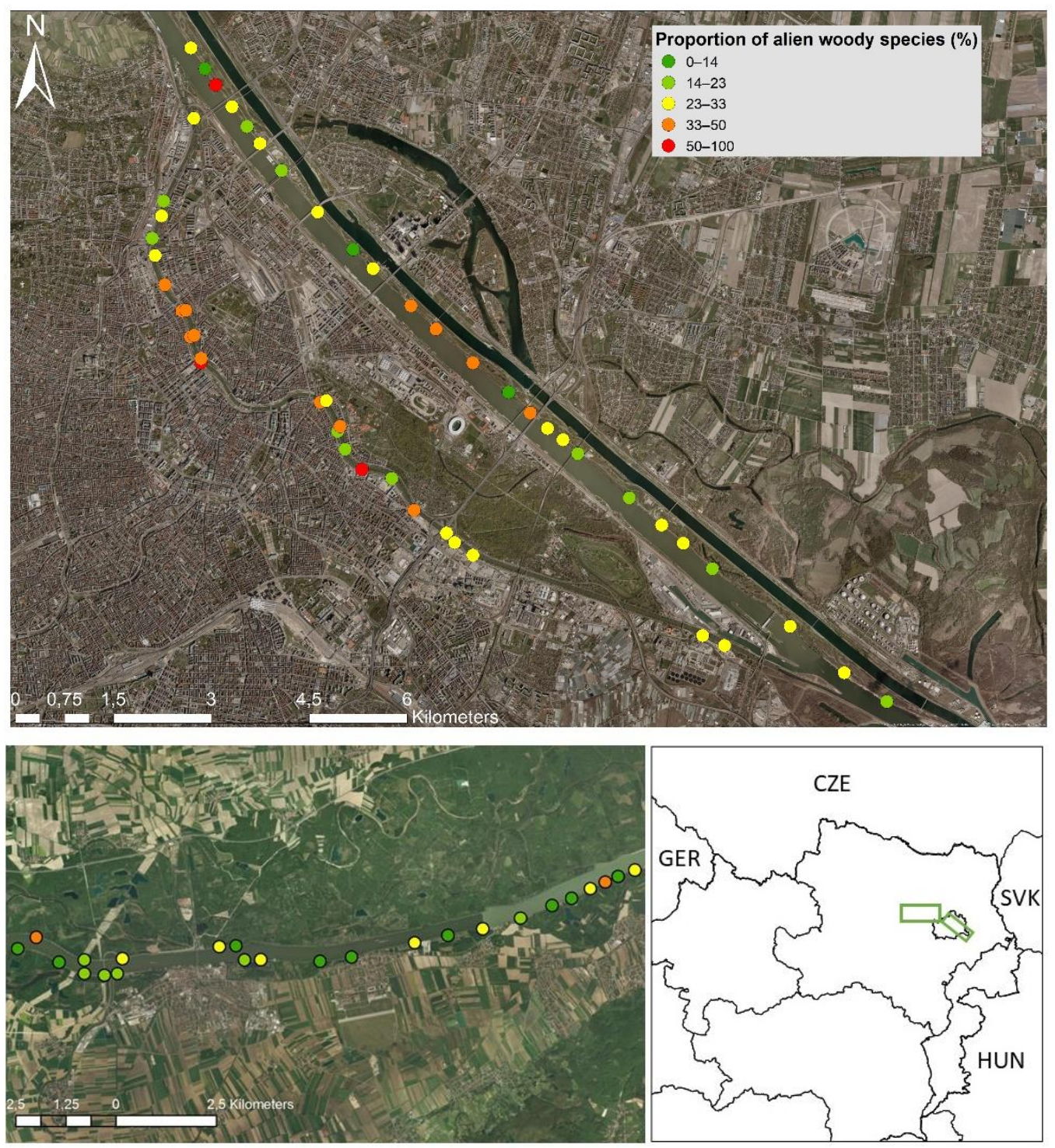

Figure 1. Overview of the location of the study region in eastern Austria and the location of the study regions. Shown are the Donaukanal (plots in the lower part of the top panel), Donauinsel (plots on the main channel of the Danube in the top panel), and the Tullner Becken (bottom). Plots are shown in different colors according to the proportion of alien woody species (i.e., number of alien species relative to number of native species per plot).

Vienna is the capital of Austria. It is a metropolis with c. 1.9 million inhabitants. It is located at the intersection of the eastern rim of the Alps—-the Wienerwald—with the Pannonian plains to the east. The Danube River runs northwest to southeast through Vienna.

We have selected three study regions along an urban-peri-urban-rural gradient, i.e., the Donaukanal (DK) in the city center of Vienna, the Donauinsel (DI) at the periphery of Vienna and a rural section of the Danube in the Tullner Becken (TB) west of Vienna (Figure S1). The "Donaukanal" is a natural branch of the Danube River which runs across a length of c. $15 \mathrm{~km}$ through the city of Vienna. It is a heavily modified water course running through densely populated areas, which is accompanied by narrow riverine groves [23]. The "Donauinsel" is a man-made island in the Danube north of the city center of Vienna that was created from 1972 to 1981 for flood protection [24]. The Danube River in the wide 
river basin section of the "Tullner Becken" is accompanied by wide floodplain forests that are located in an agriculturally dominated landscape. We selected a stretch of the Danube that extends from the western border of Vienna to the city Tulln located $25 \mathrm{~km}$ further west (Figure 1). The embankments of the Danube of all study regions are stabilized by rip-rap structures.

\subsection{Plot Selection, Species and Environmental Data Compilation}

We randomly established 25 plots at the river embankments (above the mean water level) in each of the three study regions, i.e., 75 plots in total. Sites with total woody species cover $<30 \%$ were not considered. In each plot, we collected alien-i.e., species introduced by human agency to Austria after c. 1500 CE [25]—and native woody species occurrence and abundance in each plot (Table S1). Plots had a fixed size with a length of 20 meters along the river embankment and a width of $2 \mathrm{~m}$ to ensure that the narrow gallery groves along the Danube were adequately sampled; minimum distance between plots was set to be $300 \mathrm{~m}$ to reduce spatial auto-correlation. Every woody species was recorded within a plot, and its coverage was estimated (in \%) separately for herb (i.e., woody plants of $<1 \mathrm{~m}$ height), shrub (1-5 m height), and tree layers. All field work was done in the growing season of 2018. Species nomenclature and taxonomy follow Fischer et al. [26].

For each plot, we estimated the level of anthropogenic disturbances (mostly evidence of tree removal) in three classes ranging from 1 (low, at most one cut tree stump) to 3 (high, e.g., several cut tree stumps). For analyzing the influence of adjacent human landscape transformation and local propagule pressure on woody species composition in the plots, we extracted the following data for a $500 \mathrm{~m}$ radius around the plots: human population density (extracted from Statistik Austria [27], and the proportion of land cover types that contribute to high local propagule pressure. We used the habitat map of Kuttner et al. [28], which provides gridded high-resolution data $(10 \times 10 \mathrm{~m})$ on habitat distribution in Austria. We combined all habitat types which are associated with planting of (alien) woody species in cities, i.e., parks and gardens, built up areas, roads and railways. The resulting proportion of urban habitat types (Table S2) was then used in the analyses.

\subsection{Statistical Analyses}

Woody species were assigned as either native or alien according to the inventory of alien species in Austria [25]. All recorded alien species are neophytes (i.e., recorded after 1492 in the wild) in Austria. In a first step, we analyzed the level of invasion-i.e., proportion of woody alien species relative to native woody species numbers. For doing so, we merged woody species occurrences across all three vegetation layers and converted them to species presence/absence data per plot. Second, we plotted the distribution of native and alien woody species which were found in at least 10 plots to analyze differences between study regions.

To analyze the relationship between alien species occurrence and urbanization we calculated the amount of urban habitats and the human population density within a buffer of $500 \mathrm{~m}$ around every sampling point. Further, we used binominal family Generalized Linear Mixed Models (GLMMs) using the function glmmPQL from the MASS library [29], with presence/absence data from the most common alien species in plots as dependent variable and the level of disturbance, and proportion of urban habitats and human population density in the surroundings as predictors. To account for spatial non-independence of plots within the three study regions we included the study region as random factor. Adjacent population density and proportion of urban habitats were highly correlated (0.79) and thus the joint inclusion of both variables in a single model is inappropriate [30]. Therefore, we fitted separate single-predictor models with each of these three variables for each of the five most abundant alien woody species.

To test whether alien species occur in different proportions among the three study regions, we performed a pairwise comparison of the contingency table using the pairwise.G.test-function from the RVAideMemoire library with correction for multiple testing. Pairwise differences in species numbers between study region were tested with two-sample Wilcoxon rank tests with corrections for 
multiple testing using the pairwise.wilcox.test-function from the stats library. All analyses were done in R Version 3.6.2 [31].

\section{Results}

In total, we recorded 44 native and 25 alien woody species in the 75 plots (Table S3). The highest total woody species number in a plot was 16 (Donauinsel). The highest number of native woody species was 13 (Donaukanal), and the highest number of alien woody species was 7 (Donaukanal).

We found distinct differences in proportions of alien woody species among plots and among study regions (Figure 2). The highest relative proportions of alien woody species were found at the Donaukanal and in several plots in the central section of the Donauinsel. In contrast, plots in the Tullner Becken had much lower proportions of alien woody species.

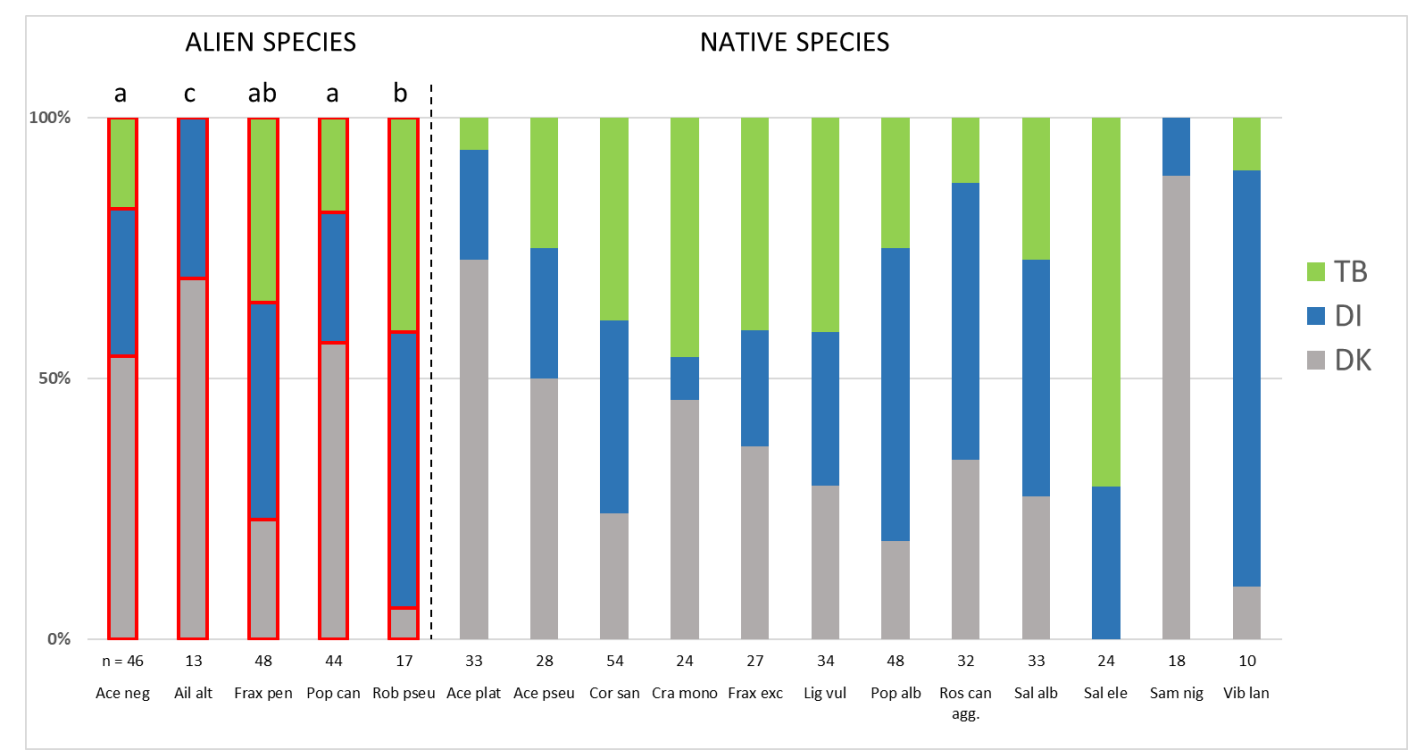

Figure 2. Distribution of occurrences (presence/absence) of the 17 most widely distributed native and alien woody species (occurrences in at least 10 plots) among the three study regions. Occurrences are shown as proportion, i.e., total number of invaded plots $=100 \%$. The number $(\mathrm{n})$ of invaded plots is also given. Abbreviations: $\mathrm{TB}=$ Tullner Becken, $\mathrm{DI}=$ Donauinsel, $\mathrm{DK}=$ Donaukanal. Species abbreviations are as follows: Ace neg = Acer negundo, Ail alt = Ailanthus altissima, Frax pen = Fraxinus pennsylvanica, Pop can $=$ Populus $x$ canadensis, Rob pseu $=$ Robinia pseudoacacia, Ace plat $=$ Acer platanoides, Ace pseu $=$ Acer pseudoplatanus, Cor san = Cornus sanguinea, Cra mono $=$ Crataegus monogyna, Frax exc $=$ Fraxinus excelsior, Lig vul = Ligustrum vulgare, Pop alb = Populus alba, Ros can agg. $=$ Rosa canina agg., Sal alb = Salix alba, Sal ele = Salix eleagnos, Sam nig = Sambucus nigra, Vib lan = Viburnum lantana . Letters above the bars indicate alien species that do not have significantly different proportions among study regions based on G-Test statistic.

We found substantial differences in the distribution of the 17 woody species that occur in at least 10 plots (Figure 2): Cornus sanguinea $(\mathrm{n}=54)$, Populus alba $(\mathrm{n}=48)$, Fraxinus pennsylvanica $(\mathrm{n}=48)$, and Populus $x$ canadensis $(n=44)$ are the most frequent native species. Five of the most common woody species are aliens: Fraxinus pennsylvanica, Populus $x$ canadensis, Acer negundo, Robinia pseudoacacia, and Ailanthus altissima. There are substantial differences in the distribution of alien woody species among the study regions. The majority of the species have more than $50 \%$ of their occurrences at the Donaukanal, while Fraxinus pennsylvanica and Robinia pseudoacacia are more abundant in the other two study regions.

For most of the five most abundant alien woody species, we found rather little differences in the occurrence across vegetation layers (Table 1). Populus $x$ canadensis was much more often found in the 
tree layer than in the shrub and herb layers, while for Acer negundo to some extent the opposite was the case.

Table 1. The number of invaded plots by the five most abundant alien woody species, shown separately for herb (h), shrub (s) and tree (t) layers.

\begin{tabular}{|c|c|c|c|c|c|c|c|c|c|c|c|c|}
\hline \multirow{2}{*}{ Species } & \multicolumn{3}{|c|}{ Donaukanal } & \multicolumn{3}{|c|}{ Donauinsel } & \multicolumn{3}{|c|}{ Tullner Becken } & \multicolumn{3}{|c|}{ Total } \\
\hline & $\mathbf{h}$ & $\mathrm{s}$ & $t$ & $\mathbf{h}$ & $\mathrm{s}$ & $t$ & h & $\mathrm{s}$ & $t$ & $\mathbf{h}$ & $\mathbf{s}$ & $t$ \\
\hline Acer negundo & 8 & 11 & 6 & 5 & 6 & 2 & 1 & 3 & 4 & 14 & 20 & 12 \\
\hline $\begin{array}{l}\text { Ailanthus } \\
\text { altissima }\end{array}$ & 3 & 2 & 4 & 1 & 1 & 2 & 0 & 0 & 0 & 4 & 3 & 6 \\
\hline $\begin{array}{c}\text { Fraxinus } \\
\text { pennsylvanica }\end{array}$ & 5 & 2 & 4 & 3 & 8 & 9 & 7 & 8 & 2 & 15 & 18 & 15 \\
\hline $\begin{array}{l}\text { Populus } x \\
\text { canadensis }\end{array}$ & 4 & 1 & 20 & 2 & 2 & 7 & 2 & 0 & 6 & 8 & 3 & 33 \\
\hline $\begin{array}{c}\text { Robinia } \\
\text { pseudoacacia }\end{array}$ & 0 & 0 & 1 & 5 & 4 & 0 & 1 & 2 & 4 & 6 & 6 & 5 \\
\hline
\end{tabular}

Median total and alien woody species numbers per plot did differ significantly between Donaukanal and the other two study regions (Figure 3). Alien woody species numbers were higher at the Donaukanal (mean alien species number per plot 3.52) compared to the other two study regions; mean alien species number per plot was 2.37 (Donauinsel) and 1.75 (Tullner Becken).
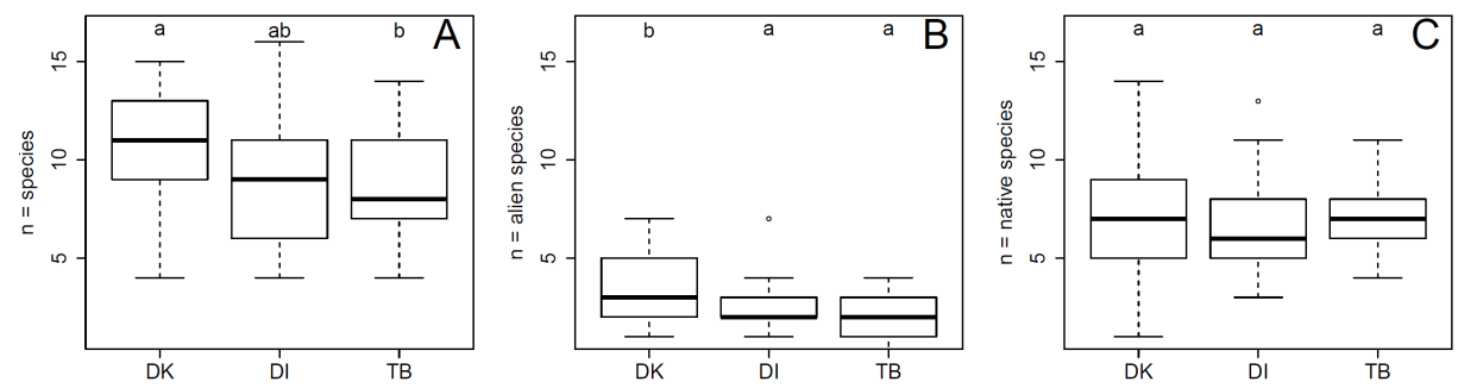

Figure 3. Boxplots of total (A), alien (B), and native (C) woody species numbers per plot in the three study regions $(\mathrm{DK}=$ Donaukanal, $\mathrm{DI}=$ Donauinsel, $\mathrm{TB}=$ Tullner Becken). Data have been combined across all vegetation layers into presence/absence data. Letters above the panels indicate groups that do not significantly differ based on results from two-sample Wilcoxon tests.

The results from the GLMMs (Table 2) show that human population density in the environs of the plots is significantly positively correlated with the presence of Acer negundo and Ailanthus altissima. Conversely, the occurrence of Robinia pseudoacacia is marginally significantly negatively correlated with surrounding human population density. Further, the occurrence of Acer negundo, Ailanthus altissima and (although marginally so) of Populus $x$ canadensis is positively associated with the proportion of urban habitats in the environs, while again, for Robinia pseudoacacia the opposite is the case. For Fraxinus pennsylvanica, we found no significant relationship. Finally, we found no evidence that the level of disturbance influenced the presence of any of the five most wide-spread alien woody species. 
Table 2. Generalized Linear Mixed Models of the occurrence (presence/absence) of the five most widespread alien woody species. As predictors we used level of disturbance in the plot, and human population density and the proportion of urban habitats in a radius of $500 \mathrm{~m}$ around each plot. Note that all models are single-predictor models of either variable as human population density and urban habitats are substantially correlated and their inclusion in one model is not appropriate. Significant predictors are shown in bold font. Given the rather low number of plots, we relaxed significance levels and considered $p$-values of $p \leq 0.1$ as significant. The study region the plots belonged to was included as random factor.

\begin{tabular}{lcccc}
\hline Alien Woody Species & Predictor & Intercept & Std. Error & $p$-Value \\
\hline \multirow{3}{*}{ Acer negundo } & population & 0.61 & 0.25 & 0.02 \\
& urban & 0.61 & 0.25 & 0.02 \\
& disturbance & 0.23 & 0.38 & 0.54 \\
\hline \multirow{3}{*}{ Ailanthus altissima } & population & 2.40 & 0.62 & $<0.01$ \\
& urban & 1.49 & 0.47 & $<0.01$ \\
& disturbance & 0.54 & 0.53 & 0.31 \\
\hline \multirow{3}{*}{ Fraxinus pennsylvanica } & population & 0.02 & 0.26 & 0.93 \\
& urban & -0.18 & 0.27 & 0.51 \\
& disturbance & -0.34 & 0.39 & 0.38 \\
\hline \multirow{3}{*}{ Populus x canadensis } & population & -0.52 & 0.43 & 0.23 \\
& urban & -1.51 & 0.83 & 0.07 \\
& disturbance & -0.65 & 0.47 & 0.18 \\
\hline \multirow{2}{*}{ Robinia pseudoacacia } & population & -1.58 & 0.32 & 0.07 \\
& urban & -0.79 & 0.38 & 0.04 \\
& disturbance & -0.01 & 0.49 & 0.98 \\
\hline
\end{tabular}

\section{Discussion}

\subsection{The Distribution of Alien Woody Species in River Corridors along an Urban-Peri-Urban-Rural Gradient}

Rivers and their adjacent habitats are known to be important corridors for the spread of a wide range of alien species [32,33]. For vascular plants, it has been shown that riverine habitats such as floodplain forests and tall-herb vegetation belong to the most heavily invaded habitats in Europe $[1,2]$. Our results support this well-established knowledge and show that woody plant species are an important component in gallery forests along the Danube in eastern Austria. The average level of invasion-i.e., the relative proportion of alien to native woody species in plots-was high across all three study regions. In several plots, there were more alien woody species than native ones, and average numbers of alien woody species per plot ranged from 1.75 (Tullner Becken) to 3.52 (Donaukanal). This high level of invasion is particularly impressive as there was no evidence of planting of woody species in the plots, and it is most likely that all woody species have established themselves. This finding indicates that gallery forests directly established at river banks are particularly susceptible to invasions. Most likely, this is a result of the interactive effects of episodic disturbances (e.g., due to flooding) that facilitate the establishment of alien plants [34] and the high likelihood that propagules are transported and deposited by running water from sources that are located upriver [32].

Still, there was a moderate decline of alien woody species richness along the urban-peri-urban-rural gradient. However, given that human settlements in general and large cities in particular are known to be associated with high local propagule pressure and thus often serve as hub for the spread of alien species $[12,15,35]$, the rather modest decline of alien species richness from urban to rural environments was rather surprising.

\subsection{The Distribution of Widespread Alien Woody Species across Study Regions and the Underlying Factors}

Of the 17 woody species that were recorded in at least 10 plots, five were alien ones. Interestingly, these five species have excellent dispersal capabilities as four of them are anemochorous, while seeds 
of the remaining one (Robinia pseudoacacia) are often dispersed in their pods by strong winds [36] (pers. obs.). Fraxinus pennsylvanica, Acer negundo and Populus $x$ canadensis were particularly widespread with occurrences in more than 40 plots. Fraxinus pennsylvanica, which is native to eastern USA, is one of the most rapidly spreading woody alien species in Central Europe, and it is most abundant in hardwood floodplain forests of large lowland rivers [33,37], where its spread is facilitated by hydrochory [14]. In Austria, it is used as ornamental species in urban public spaces and sometimes it is planted for forestry purposes. Along the Danube, the species has spread considerably only since the 1990s [38], and recently it has become managed in floodplain forests of the Danube National Park east of Vienna (G. Oitzinger pers. comm.). Due to its rapid ongoing spread, this species has been recorded with higher frequency in the herb (14 plots) and shrub layers (20 plots), but somewhat less in the tree layer (12 plots). Acer negundo, which is native to northeastern US, has also spread considerably in Central Europe in recent decades. This species was solely introduced as an ornamental tree, as its wood has no commercial value. It is most abundant in lowland softwood floodplain forests, where it can outcompete the native willow species (Salix spp.) as it is more shade-tolerant [38]. In the Danube National Park, there have been substantial recent eradication efforts (G. Oitzinger per. comm). Acer negundo is most widespread in the plots of the Donaukanal-study region, and high human population density and large proportion of urban habitats significantly explain its current distribution in the study plots. This finding indicates that spread from urban plantings seems to drive its invasion into more rural river sections. Populus $x$ canadensis is a hybrid of a North American (P. deltoides) and European (P. nigra) parental species, which is widely cultivated for its fast growth mostly in floodplain forests [39]. Molecular studies revealed that up to $10 \%$ of poplar offspring in Europe consists of back crosses between Populus $x$ canadensis and $P$. nigra threatening the native poplar species [39]. Interestingly, the majority of invaded plots is located in the Donaukanal study region, although this species is widely planted in floodplain forests along rural river sections such as the Tullner Feld.

With less than 20 plots invaded, Ailanthus altissima and Robinia pseudoacacia are both substantially less widely distributed than the above discussed species. Further, these two species differ also ecologically as they are tolerant to dry soils, can re-sprout by root suckers, and thus are tolerant to anthropogenic disturbance and most widespread in urban ruderal woodlands [22,33,40]. Ailanthus altissima, which is native to East Asia, is limited to plots in an urban and peri-urban context and its occurrence is significantly explained by a high proportion of urban habitats and high population density. This species has been widely planted as ornamental tree in urban Vienna during the 19th century [41,42]. In recent decades, it has spread strongly in Vienna and has possibly become the most characteristic alien urban woody species [43]. Surprisingly, the distribution of Robinia pseudoacacia differs strongly from the preceding species: it is most abundant in rural and peri-urban plots, but only rarely occurs in plots at the Donaukanal. Accordingly, human population density and the proportion of urban habitats negatively affect its distribution. Possibly, this difference in distribution can be explained by the rather widespread distribution of Robinia pseudoacacia in floodplain forests of the Danube River [33,44], whereas this species is rather rarely planted or occurring as escaped tree in urban Vienna. Due to its ability to fix nitrogen, this tree species has strong impacts on species composition of invaded plant communities [45].

\subsection{Implications for Management and Conclusions}

Rivers and their accompanying habitats are highly important-yet increasingly threatened-corridors for biodiversity conservation. In cities, additional factors such as recreation further add to the high importance of rivers for urban ecology and human livelihoods. The high abundance of most alien woody species in herb and shrub layers indicate that species are still spreading.

Managing alien woody species in urban and peri-urban contexts has to weigh potential benefits (e.g., limiting impacts on native species, reducing or halting the spread to high conservation value areas such as protect areas such as the Danube National Park east of Vienna against the benefits that woody 
species bring about (e.g., providing shade, reducing microclimatic extremes). Therefore, management needs to be adapted and fine-tuned to specific situations [46].

We argue that while several of the alien woody species we have found are known to cause detrimental impacts in habitats of high conservation value [44,47], management should prioritize rural sections of the Danube River. Currently, such management is on-going on a large scale in the Danube National Park [33]. However, we believe that managing alien woody species in urban and peri-urban sites is not appropriate in most cases and useful, given that re-invasion is likely in most cases (from planted trees in adjacent urban green spaces). Given that seeds are mostly dispersed downstream (and thus invasion risks are higher in rural rivers sections downstream of cities), we believe that such an approach should include monitoring—and management when deemed necessary—of alien woody species spread in urban riverine sites that are located towards the downstream side of the city. We acknowledge that following this recommendation will entail the implicit recognition that gallery forests along the urban sections of the Danube will contain a substantial—and likely further increasing-proportion of alien woody species.

Supplementary Materials: The following are available online at http:/www.mdpi.com/2071-1050/12/6/2185/s1, Figure S1. Illustrative pictures of the study regions; Table S1. Alien and native woody species composition in the 75 study plots; Table S2. Survey data and explanatory variables used in the analyses; Table S3. Overview on the recorded woody species in the 75 plots.

Author Contributions: S.W. and F.E. designed the study; S.W. collected and analyses field data, and led the writing; F.E. critically revised the manuscript; and D.M. contributed to analyses and writing. All authors have read and agreed to the published version of the manuscript.

Funding: F.E. acknowledges funding by the Austrian Science Foundation FWF. Open Access Funding by the Austrian Science Fund (FWF), grant number: I 3757-B29.

Acknowledgments: We appreciate the helpful comments of three anonymous reviewers and of the Editor of the Special Issue, Ingo Kowarik, on this manuscript.

Conflicts of Interest: The authors declare no conflict of interest.

\section{References}

1. Winter, M.; Schweiger, O.; Klotz, S.; Nentwig, W.; Andriopoulos, P.; Arianoutsou, M.; Basnou, C.; Delipetrou, P.; Didžiulis, V.; Hejda, M.; et al. Plant extinctions and introductions lead to phylogenetic and taxonomic homogenization of the European flora. Proc. Natl. Acad. Sci. USA 2009, 106, 21721-21725. [CrossRef]

2. Chytrý, M.; Maskell, L.C.; Pino, J.; Pyšek, P.; Vilà, M.; Font, X.; Smart, S.M. Habitat invasions by alien plants: A quantitative comparison among Mediterranean, subcontinental and oceanic regions of Europe. J. Appl. Ecol. 2008, 45, 448-458. [CrossRef]

3. Chytrý, M.; Pyšek, P.; Tichý, L.; Knollová, I.; Danihelka, J. Invasions by alien plants in the Czech Republic: A quantitative assessment across habitats. Preslia 2005, 77, 339-354.

4. Pyšek, P. Alien and native species in Central European urban floras: A quantitative comparison. J. Biogeogr. 1998, 25, 155-163. [CrossRef]

5. Aronson, M.F.J; La Sorte, F.A.; Nilon, C.H.; Katti, M.; Goddard, M.A.; Lepczyk, C.A.; Warren, P.S.; Williams, N.S.G.; Cilliers, S.; Clarkson, B.; et al. A global analysis of the impacts of urbanization on bird and plant diversity reveals key anthropogenic drivers. Proc. R. Soc. B Biol. Sci. 2014, 281, 20133330. [CrossRef]

6. Onandia, G.; Schittko, C.; Ryo, M.; Bernard-Verdier, M.; Heger, T.; Joshi, J.; Kowarik, I.; Gessler, A. Ecosystem functioning in urban grasslands: The role of biodiversity, plant invasions and urbanization. PLoS ONE 2019, 14, e0225438. [CrossRef]

7. Kowarik, I. On the role of alien species in urban flora and vegetation. In Urban Ecology; Marzloff, J.M., Shulenberger, E., Endlicher, W., Alberti, M., Bradley, G., Ryan, C., Simon, U., ZumBrunnen, C., Eds.; Springer: Boston, MA, USA, 2008; pp. 321-338.

8. Kühn, I.; Brandl, R.; Klotz, S. The flora of German cities is naturally species rich. Evol. Ecol. Res. 2004, 6, 749-764.

9. Mayer, K.; Haeuser, E.; Dawson, W.; Essl, F.; Kreft, H.; Pergl, J.; Pyšek, P.; Weigelt, P.; Winter, M.; Lenzner, B.; et al. Naturalization of ornamental plant species in public green spaces and private gardens. Biol. Invasions 2017, 19, 3613-3627. [CrossRef] 
10. Pilsl, P.; Schröck, C.; Kaiser, R.; Gewolf, S.; Nowotny, G.; Stöhr, O. Neophytenflora der Stadt Salzburg. Sauteria. Verlag Alexander Just Dorfbeuern/Salzburg 2008, 17, 1-608.

11. von der Lippe, M.; Kowarik, I. Do cities export biodiversity? Traffic as dispersal vector across urban-rural gradients. Divers. Distrib. 2008, 14, 18-25. [CrossRef]

12. Williams, N.S.G.; Hahs, A.K.; Vesk, P.A. Urbanisation, plant traits and the composition of urban floras. Perspect. Plant. Ecol. Evol. Syst. 2015, 17, 78-86. [CrossRef]

13. Säumel, I.; Kowarik, I. Propagule morphology and river characteristics shape secondary water dispersal in tree species. Plant. Ecol. 2013, 214, 1257-1272. [CrossRef]

14. Schmiedel, D.; Tackenberg, O. Hydrochory and water induced germination enhance invasion of Fraxinus pennsylvanica. For. Ecol. Manag. 2013, 304, 437-443. [CrossRef]

15. Säumel, I.; Kowarik, I. Urban rivers as dispersal corridors for primarily wind-dispersed invasive tree species. Landsc. Urban. Plan. 2010, 94, 244-249. [CrossRef]

16. Pyšek, P.; Richardson, D. Traits associated with invasiveness in alien plants: Where do we stand? In Biological Invasions; Nentwig, W., Ed.; Springer: Berlin/Heidelberg, Germany, 2007; pp. 97-125.

17. Krumm, F.; Vitkova, L. Introduced Tree Species in European Forests: Opportunities and Challenges; European Forest Institute: Joensuu, Finland, 2016; pp. 1-426.

18. Richardson, D.M.; Rejmánek, M. Trees and shrubs as invasive alien species-A global review. Divers. Distrib. 2011, 17, 788-809. [CrossRef]

19. Botham, M.S.; Rothery, P.; Hulme, P.E.; Hill, M.O.; Preston, C.D.; Roy, D.B. Do urban areas act as foci for the spread of alien plant species? An assessment of temporal trends in the UK. Divers. Distrib. 2009, 15, 338-345. [CrossRef]

20. Muhar, S.; Muhar, A.; Siegrist, D.; Egger, G. Rivers of the Alps: Diversity in Nature and Culture; Haupt Verlag: Bern, Switzerland, 2019; pp. 1-480.

21. ZAMG. Digitaler Klimaatlas Österreichs; Zentralanstalt für Meteorologie und Geodynamik: Vienna, Austria, 2010.

22. Ließ, N.; Drescher, A. Ailanthus altissima spreading in the Danube National Park-possibilities of control. Neobiota 2008, 7, 84-95.

23. Buchmann, B.; Sterk, H.; Schickl, R. Der Donaukanal: Geschichte-Planung-Ausführung. Available online: https://www.wien.gv.at/stadtentwicklung/studien/pdf/b003547.pdf (accessed on 29 February 2020).

24. Michlmayr, F. Die Grundzüge des Donauinsel-Projekts. Denisia 2002, 3, 11-25.

25. Essl, F.; Rabitsch, W. Neobiota in Österreich; Umweltbundesamt: Dessau-Roßlau, Germany, 2002; pp. 1-432.

26. Fischer, M.A.; Oswald, K.; Adler, W. Exkursionsflora für Österreich, Liechtenstein, Südtirol; Biologiezentrum der oö: Linz, Austria, 2008; pp. 1-1392.

27. Statistik Austria. Regionalstatistische Rastereinheiten. Available online: http://www.statistik.at/web_de/ klassifikationen/regionale_gliederungen/regionalstatistische_rastereinheiten/index.html (accessed on 12 December 2019).

28. Kuttner, M.; Essl, F.; Peterseil, J.; Dullinger, S.; Rabitsch, W.; Schindler, S.; Hülber, K.; Gattringer, A.; Moser, D. A new high-resolution habitat distribution map for Austria, Liechtenstein, southern Germany, South Tyrol and Switzerland. Eco.mont 2015, 7, 18-29. [CrossRef]

29. Brian, A.; Venables, B.; Bates, D.M.; Firth, D.; Ripley, M.B. Package 'MASS'. Available online: https: //cran.r-project.org/web/packages/MASS/MASS.pdf (accessed on 12 December 2019).

30. Dormann, C.F.; Elith, J.; Bacher, S.; Buchmann, C.; Carl, G.; Carré, G.; Marquéz, J.R.G.; Gruber, B.; Lafourcade, B.; Leitão, P.J.; et al. Collinearity: A review of methods to deal with it and a simulation study evaluating their performance. Ecography 2013, 36, 27-46. [CrossRef]

31. R Core Team. R: A Language and Environment for Statistical Computing. Available online: https: //www.R-project.org/ (accessed on 14 January 2020).

32. Rinaldo, A.; Gatto, M.; Rodriguez-Iturbe, I. River networks as ecological corridors: A coherent ecohydrological perspective. Adv. Water Resour. 2018, 112, 27-58. [CrossRef] [PubMed]

33. Höfle, R.; Dullinger, S.; Essl, F. Different factors affect the local distribution, persistence and spread of alien tree species in floodplain forests. Basic Appl. Ecol. 2014, 15, 426-434. [CrossRef]

34. Catford, J.A.; Daehler, C.C.; Murphy, H.T.; Sheppard, A.W.; Hardesty, B.D.; Westcott, D.A.; Rejmánek, M.; Bellingham, P.J.; Pergl, J.; Horvitz, C.C.; et al. The intermediate disturbance hypothesis and plant invasions: Implications for species richness and management. Perspect. Plant. Ecol. Evol. Syst. 2012, 14, 231-241. [CrossRef]

35. Essl, F.; Mang, T.; Moser, D. Ancient and recent alien species in temperate forests: Steady state and time lags. Biol. Invasions 2012, 14, 1331-1342. [CrossRef] 
36. Morimoto, J.; Kominami, R.; Koike, T. Distribution and characteristics of the soil seed bank of the black locust (Robinia pseudoacacia) in a headwater basin in northern Japan. Landscape. Ecol. Engen. 2010, 6, 193-199. [CrossRef]

37. Prots, B.; Drescher, A.; Vykhor, B. Invasion ecology of Green ash Fraxinus pennsylvanica Marsh. in the Transcarpathia (Ukraine). Biol. Syst. 2011, 3, 269-276.

38. Walter, J.; Essl, F.; Englisch, T.; Kiehn, M. Neophytes in Austria: Habitat preferences and ecological effects. Neobiota 2005, 6, 13-25.

39. Smulders, M.J.M.; Beringen, R.; Volosyanchuk, R.; Vanden Broeck, A.; van der Schoot, J.; Arens, P.; Vosman, B. Natural hybridisation between Populus nigra L. and P. $x$ canadensis Moench. Hybrid offspring competes for niches along the Rhine river in the Netherlands. Tree Genet. Genom. 2008, 4, 663-675. [CrossRef]

40. Wickert, K.L.; O’Neal, E.S.; Davis, D.D.; Kasson, M.T. Seed production, viability, and reproductive limits of the invasive Ailanthus altissima (tree-of-heaven) within invaded environments. Forests 2017, 8, 226. [CrossRef]

41. Neilreich, A. Flora von Wien. Eine Aufzählung der in den Umgebungen Wiens Wild Wachsenden oder im Grossen Gebauten Gefäßpflanzen, Nebst einer Pflanzengeografischen Übersicht; F. Beck Universitäts-Buchhandlung: Vienna, Austria, 1849.

42. Wessely, J. Wiener Alleebäume. Oesterr Monatsschr. Forstwes. 1871, 21, 417-420.

43. Kowarik, I.; Säumel, I. Biological Flora of Central Europe: Ailanthus altissima (Mill.) Swingle. Perspect. Plant. Ecol. Evol. Syst. 2007, 8, 207-237. [CrossRef]

44. Drescher, A.; Magnes, M. Anthropochoren im Nationalpark Donau-Auen-Ziel von Bekämpfungsmaßnahmen oder Bereicherung der Biodiversität? Wallner, R., Ed.; Aliens. Neobiota in Österreich: Vienna, Austria, 2002; pp. 141-144.

45. Cierjacks, A.; Kowarik, I.; Joshi, J.; Hempel, S.; Ristow, M.; von der Lippe, M.; Weber, E. Biological Flora of the British Isles: Robinia pseudoacacia. J. Ecol. 2013, 101, 1623-1640. [CrossRef]

46. Gaertner, M.; Novoa, A.; Fried, J.; Richardson, D.M. Managing invasive species in cities: A decision support framework applied to Cape Town. Biol. Invasions 2017, 19, 3707-3723. [CrossRef]

47. Lapin, K.; Oettel, J.; Steiner, H.; Langmaier, M.; Sustic, D.; Starlinger, F.; Kindermann, G.; Frank, G. Invasive alien plant species in unmanaged forest reserves, Austria. Neobiota 2019, 96, 71-96. [CrossRef]

(C) 2020 by the authors. Licensee MDPI, Basel, Switzerland. This article is an open access article distributed under the terms and conditions of the Creative Commons Attribution (CC BY) license (http://creativecommons.org/licenses/by/4.0/). 